\title{
A Note on the Romanisation of Chinese Names
}

In this new edition, I have retained the Wade-Giles system so long familiar to Western readers, for, while it is not perfect, it is easier to pronounce than the official pinyin system. Both forms will be found in the index. For well-known place names (e.g., Peking, Canton), I have followed the usual, and I think correct, custom of using the Anglicised form, as is done, for instance, with Rome, Athens, Munich.

In the case of some modern Chinese artists, I have given the names in the form they themselves adopted in the West: e.g., Zao Wou-ki (Chao Wu-chi), Chang Dai Chien (Chang Ta-ch'ien). 
